\title{
Bimodal pollination system in rare endemic Oncocyclus irises (Iridaceae) of Lebanon
}

\author{
Arnaud Monty, Layla Saad, and Grégory Mahy
}

\begin{abstract}
Pollination systems based on indirect rewards, such as heat and shelter, have seldom been studied. Plantpollinator interactions were characterized in Iris cedretii Dinsmore ex Chaudhary and Iris sofarana subsp. kasruwana Dinsmore ex Chaudhary, rare endemic Lebanese Oncocyclus irises exhibiting potential adaptation to shelter pollination. Despite a diversity of floral visitors (47 species), only two groups of Anthophoridae male bees (Xylocopa spp. and Eucera spp.) could be considered as efficient pollinators on the basis of frequency of visits, visiting behaviour, and pollen load. Lebanese Oncocyclus irises showed a bimodal pollination system with (1) diurnal visits at low rates but with potentially large pollen transfers by Xylocopa bees, exhibiting a foraging-like behaviour, principally during warm periods of the day and (2) sheltering, especially Eucera male bees, during night and day when the weather is changeable. Refuge occurrence in flowers was more important during the night (27\%) than during the day (12\%) and, for daytime, during cloudy or windy than sunny conditions. It also varied depending on the exposure of floral tunnels. Visitation rates of both day-visiting Xylocopa and night-sheltering Eucera were negatively associated with an increase of the number of flowers per clump. No experimental evidence was found showing that the principal advantage for male bees to shelter in Iris flowers was to fly earlier in the morning.
\end{abstract}

Key words: Eucera, pollination, heat reward, male solitary bees, sheltering, Xylocopa.

Résumé : Les systèmes de pollinisation basés sur des récompenses indirectes, telles que la chaleur ou le refuge, ont été peu étudiés. Les interactions plante-pollinisateur ont été caractérisées chez Iris cedretii Dinsmore ex Chaudhary et Iris sofarana subsp. kasruwana Dinsmore ex Chaudhary, des iris Oncocycles libanais, rares et endémiques, présentant un potentiel d'adaptation à la pollinisation par refuge. Malgré une diversité de visiteurs floraux (47 espèces), seuls deux groupes d'abeilles mâles Antophoridae (Xylocopa sp. et Eucera sp.) peuvent être considérés comme des pollinisateurs efficaces sur base de la fréquence de visite, le comportement de visite et la charge en pollen. Les iris Oncocycles libanais présentent un système de pollinisation bimodale avec (1) des visite diurnes de faibles fréquence mais avec des transferts de pollen potentiellement importants réalisés par les abeille Xylocopes, présentant un comportement similaire au butinage, en particulier pendant les périodes chaudes de la journée et (2) du refuge, en particulier des Eucères mâles, pendant la nuit, et le jour quand le climat est changeant. La fréquence de refuge dans les fleurs est plus importante la nuit (27 \%) que le jour (12\%) et, pour le jour, dans des conditions pluvieuses ou venteuses plutôt qu'ensoleillées. Le refuge varie aussi en fonction de l'exposition des tunnels floraux. Le taux de visite des Xylocopes, visiteurs de jour et des Eucères, réfugiés de nuit, a été associé négativement avec une augmentation du nombre de fleurs par touffe florale. Aucune preuve expérimentale n'a pu mettre en évidence que le principal avantage au refuge des abeilles mâles dans les fleurs d'iris était de s'envoler plus tôt le matin.

Mots clés : Eucera, pollinisation, récompense par la chaleur, abeilles mâles solitaires, abri, Xylopa.

\section{Introduction}

In zoophilous pollination systems, plant and pollinator species share mutualistic interactions, each being advantageous for the other (Kearns et al. 1998; Herrera and Pellmyr 2002; Dafni et al. 2005). Given the important dependence of sessile zoophilous Angiosperms to their pollen vectors, it is no surprise to find a huge diversity of floral structures linked to pollinator attraction strategies (Baker and Hurd

Received 22 December 2005. Published on the NRC Research Press Web site at http://canjbot.nrc.ca on 21 September 2006.

A. Monty, ${ }^{1}$ L. Saad, ${ }^{2,1}$ and G. Mahy. Laboratory of Ecology, Gembloux Agricultural University, Passage des Déportés 2, B5030 Gembloux, Belgium.

${ }^{1}$ These authors contributed equally to this work.

${ }^{2}$ Corresponding author (e-mail: saad.1@fsagx.ac.be).
1968; Proctor and Yeo 1973; Kevan and Baker 1983; Kevan 2001). Attractants include the visual impact of colour or flower size as well as the production of an odour (Faegri and Van Der Pijl 1980; Ishii and Sakai 2001; Passarelli and Bruzzone 2004), but attraction is most often based on the possibility for the animal to find a reward, such as nectar (Nilsson 1988; Kearns and Inouye 1993; Emms and Arnold 2000; Kearns 2001; Molina-Freaner et al. 2004), pollen (Emms and Arnold 2000; Kearns 2001; Fleming and Nicolson 2002), oil (Herrera and Pellmyr 2002), or other substances (Faegri and Van Der Pijl 1980).

Rewards may also be more indirect. Flowers can offer protection and act as a sheltering place (Faegri and Van Der Pijl 1980). Heat is also considered as a reward for the floral visitor (Faegri and Van Der Pijl 1980; Sapir et al. 2005). Heat can either be generated by the plant by active thermogenesis (Seymour and Schultze-Motel 1997; Gibernau et al. 
1999; Thien et al. 2000; Seymour et al. 2003) or passively by retention often linked to heliotropism (Heinrich and Raven 1972; Kevan 1975; Totland 1996; Galen and Stanton 2003). The relationships between indirect rewards and pollination have been less explored than the traditional relationships with direct rewards; more studies towards these pollination systems are needed to assess their importance.

Oncocyclus irises provide a suitable model to explore pollination systems based on indirect rewards such as sheltering and heat gain. They are xerophytic plants native of semidesert areas of the Middle East. In these Iris species, the stems bear a solitary large flower, which has bearded falls with a central dark patch: the onco spot (Mathew 1989). Although Oncocyclus Iris flowers are among the largest in the Middle East flora, they lack nectaries (Avishai 1977) and therefore offer no such reward to pollinators. In Israel, pollination was first proposed to be performed by large, long-distance flying solitary bees of the genus Xylocopa and Anthophora (Avishai and Zohary 1980). In contrast, Sapir et al. (2005) found that Oncocyclus irises in Israel were pollinated only by night-sheltering male bees from a single genus (Eucera spp.). They linked this phenomenon to heat retention favoured by the dark colour of flowers. Because of the conflicting evidence and hypotheses on the pollination systems of Oncocyclus irises, more studies are needed to assess the importance of sheltering and heat reward in those species. In addition, the considerable environmental variation encountered in the Mediterranean basin along altitudinal gradients is likely to induce variation in pollination guilds among related plant species.

The endemic Lebanese Oncocyclus irises considered in the present study also bear large $(10-15 \mathrm{~cm})$ dark purple flowers that may be suitable for sheltering phenomena. Study of their pollination system is also of great importance for their conservation. The status of Lebanese Oncocyclus is of concern, as most of them are listed as endangered by the IUCN (International Union for Conservation of Nature and Natural Resources (IUCN) 2000). Numerous studies have shown that insect visitation may be significantly influenced by the spatial arrangement of flowers in the floral display and in a given neighborhood (e.g., Grindeland et al. 2005; Kirchner et al. 2005). Patch size and flower density may influence the degree to which pollinators are attracted to a patch, affecting visitation rates to the patch as a whole, as well as on a per-plant or per-flower basis (Groom 1998). Such variation in insect visitation may significantly affect seed set and is an important component of individual plant fitness (Kirchner et al. 2005; Tarasjev 2005). To our knowledge, effect of flower density on pollinators visitation pattern has never been explored in the sheltering pollination system. As Lebanese Oncocyclus irises are rhizomatous clonal species and display a typical clumpy distribution of ramets with a high variation of flowers number per clump, they are an adequate model for such study.

In this paper, we report a detailed study on the pollination system of Lebanese endemic Oncocyclus irises. First we aimed at assessing the relative importance of the sheltering phenomenon as compared with floral visits. For this, the insect fauna associated with Oncocyclus populations was identified. The pollination efficiency of the various groups of insects was assessed indirectly on the basis of frequency of visits, visiting behaviour, and pollen transport capacity. The effect of the population spatial structure on flower visiting and on sheltering was also considered. Finally, we tested the hypothesis that sheltering is linked to early morning heat gain.

\section{Materials and methods}

\section{Study organisms and study sites}

Lebanese endemic Oncocyclus are a complex of closely related taxa, represented by distinct populations replacing each other over short geographical distances $(15-20 \mathrm{~km})$. According to Rix (1997), they include Iris cedretii Dinsmore ex Chaudhary, Iris sofarana subsp. kasruwana Dinsmore ex Chaudhary, and Iris sofarana subsp. sofarana Foster. They are all natives of high-altitude habitats (between 1500 and $2000 \mathrm{~m}$ ). They grow preferentially on southwest rocky slopes, and the spatial extent of populations is limited. There are two populations left per taxon, ranging in size from $500 \mathrm{~m}^{2}$ to a few hectares (L. Saad, data not included). These populations are presently considered as separate species or subspecies, but recent evidence in other Oncocyclus groups suggests that they could be considered as one taxon exhibiting geographical variation (Sapir and Shmida 2002).

Lebanese Oncocyclus exhibit the typical ternary floral structure of Iris species (Fig. 1a). The standards (inner tepals) are large and dressed. The large falls (outer tepals) are in their proximal part the bases of three "tunnels", from now on referred to as "pollination tunnels". Outside these tunnels, the falls bear an onco spot, the dark central patch typical of the section, which varies in shape and size according to taxa but is always dark purple, to almost black in colour. The top of the pollination tunnel is formed by the flat and petaloid style, of which the stigma is located at the extremity, at the entrance to the tunnel (Fig. 1b). A single anther is located at the top of the pollination tunnel, against the style.

The species considered in this study typically bear a flower $10-15 \mathrm{~cm}$ large, on a stem up to $40 \mathrm{~cm}$ in height. The falls and the standards are densely spotted and veined with purple-maroon, on a white background colour. They flower from May to June and produce large capsules bearing around 30 large arillated seeds. As rhizomatous species, they are also able to reproduce vegetatively and show a typical clumped growth habit (Fig. 1c), leading to a clustered spatial distribution of ramets.

In this study, we concentrated our analysis on populations known as I. cedretii Dinsmore ex Chaudhary, endemic to the Lebanese mountains (1800-2000 m), and known from only two sites. The main study was carried out in The Cedars population, which is the largest (altitude is $1865 \mathrm{~m}$, area is $40000 \mathrm{~m}^{2}$ ). In this population, irises have a fragmented distribution (four subpopulations) and cover several hills and plateaus. Additional observations of the pollinator guilds were conducted in the second known population of I. cedretii, in Ain El Haramiyé, (altitude is $1840 \mathrm{~m}$, area is $500 \mathrm{~m}^{2}$ ). This population was small and threatened by agricultural expansion. Further observations were also made in a large population of Iris sofarana subsp. kasruwana, in Laqlouq (altitude of $1555 \mathrm{~m}$, area of $55000 \mathrm{~m}^{2}$ ). 
Fig. 1. (a) Floral structure of Iris cedretii. (b) Eucera male bees aggregate in the pollination tunnel of I. cedretii (1, standard; 2, style; 3 , fall with the onco spot; 4, stigma). (c) Clumpy distribution of I. cedretii in Ain El Haramiyé.
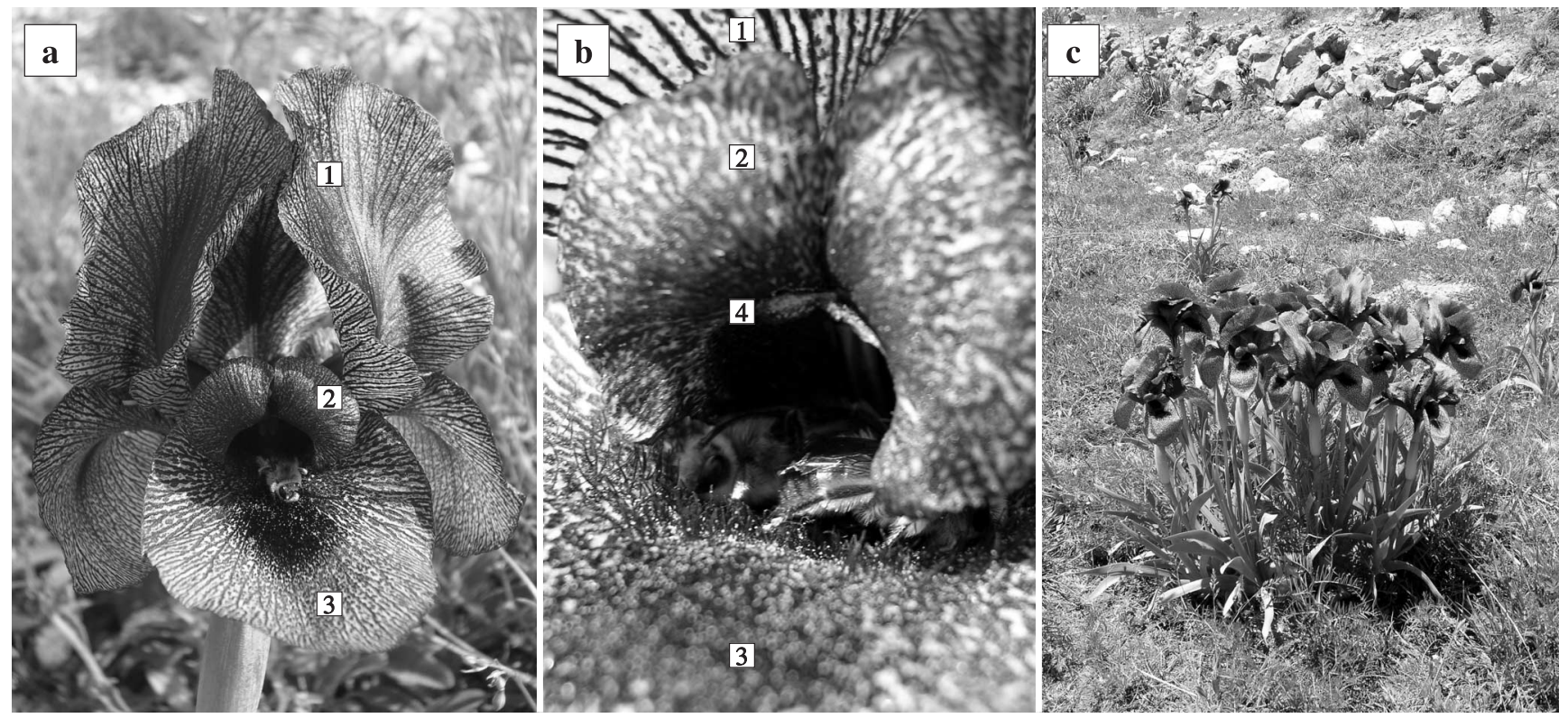

\section{Floral longevity and receptivity}

In The Cedars population, 12 floral buds were randomly marked before opening on 27 May 2004. They were checked every day until complete wilt, to estimate floral longevity. Twelve more buds were bagged just before opening and were further artificially cross-pollinated using pollen of several different flowers (1) at the first day of flower opening $(N=6)$ and (2) at the first wilting signs to test for maximal receptivity $(N=6)$. The stigma was considered as receptive if fruit developed following pollination.

\section{Diurnal observations of visitors}

In The Cedars population, $30 \mathrm{~min}$ observation sessions were performed during the flowering season (from 9 May to 9 June 2004) or a total of $72 \mathrm{~h}$ of observation. They were equally distributed through the day, from 0700 to $1900 \mathrm{~h}$, and were chosen to cover the three main climatic conditions (sunny, cloudy, and windy) at the same frequency. During these observations, the observer was located about 1-2 $\mathrm{m}$ away from a flowering clump containing 1-26 flowers. A flowering clump was defined as a group of flowering ramets spatially isolated from others. Any insect that landed on the flower or entered the pollination tunnel was recorded, captured with a net, and killed to be subsequently identified. Their behaviour was noted as: (1) "foragers" (if entering the floral tunnel, then leaving), (2) "sheltered" (if entering the floral tunnel or found inside at the beginning of the observation and remaining inside for at least $1 \mathrm{~min}-$ this length of time was chosen linked to previous field observations), (3) "floriphageous" (if eating floral tissues), and (4) "accidental" (any other case).

In the small $I$. cedretii population of Ain El Haramiyé, 60 additional sessions of $30 \mathrm{~min}(30 \mathrm{~h})$ diurnal observations were conducted from 4 to 12 May 2004. This period covered the flowering period of the species in this site. In the population of Iris sofarana subsp. kasruwana, 14 sessions of 30 min diurnal observations $(7 \mathrm{~h})$ were conducted on 14 May 2004.

\section{Night and day sheltering}

To assess the frequency of night sheltering, 14 sampling sessions were performed at least $0.5 \mathrm{~h}$ before sunrise in The Cedars population, from 12 May to 10 June 2004, by sampling the three tunnels of 50 flowers, randomly selected, inside one subpopulation (the same subpopulation was never sampled over 2 consecutive days). When insects were found in a flower, the following data were collected: the number of specimens of each species, the orientation of the occupied tunnels (eight categories), the distance between two stigmas as an estimate of flower diameter (Sapir et al. 2002), and the flower height measured as the distance between the soil and the base of the falls (outer petals). At least one specimen of each species was captured, killed, and pinned for further identification.

From 10 May to 9 June 2004, 27 sampling sessions were performed during the daytime using the same method as for night-shelter sampling. They were equally distributed from sunrise to sunset, and covered the three main climatic conditions (sunny, cloudy, and windy) at the same occurrence.

The dispersion of insects among flowers (clumped or homogeneous) was estimated with the "variance/mean ratio" (VMR) for each insect species as follows:

\section{[1] $\quad \mathrm{VMR}=s^{2} \bar{x}$}

where $s^{2}$ is the variance and $\bar{x}$ is the mean number of individuals per flower.

VMR values greater than 1.0 correspond with existence of "clusters" and show an aggregation behaviour of bees among flowers. Smaller values (VMR $<1.0)$ are linked to a more-uniform-than-random distribution, i.e., mutual avoidance of insects among flowers. VMR values equal to 11.0 correspond with existence of "clusters" and show an aggre- 
gation behaviour of bees among flowers. Smaller values (VMR < 1.0) are linked to a more-uniform-than-random distribution, i.e., mutual avoidance of insects among flowers. VMR values equal to 1 correspond with a Poisson distribution (Sokal and Rohlf 2003). A $\chi^{2}$ goodness-of-fit testing to a Poisson distribution was performed. Height and diameter of the flowers sheltering the different groups of refugees were compared with the mean flower height and diameter of those in the population measured in 2003 with a $t$ test.

\section{Influence of flower spatial pattern on frequency of visit and the sheltering phenomenon}

To test for the effect of grouping of flowers in clumps on pollinator attraction, the number of flowers in the observed or sampled clumps was recorded during the diurnal observation of visitors as well as during the shelter samplings. Moreover, but for sheltering only, flower density in a $1 \mathrm{~m}^{2}$ circle around the flower was also recorded to further evaluate the influence of local density on sheltering behaviour. Because the rate of visit was rather low, resulting in numerous zero values for individual observation sessions, the data were pooled for clumps with similar flower number, and a global rate of visit was estimated for each class. Cutoff for the delimitation of flower number class was chosen in a way to obtain similar sample size (number of observation sessions) among the flower number classes.

\section{Pollen quantification}

To estimate the pollination efficiency of the main visitors (including sheltered insects) pollen was quantified on the body of 270 insects captured in The Cedars population during the diurnal observation sessions, and belonging to the major groups of flower visitors, using Beattie's method (Beattie 1971). Pollen was collected from all body parts using a stained gelatine cube. The cube was melted on a microscope slide and homogenized. The number of Iris and non-Iris pollen grains was then counted under the microscope in one randomly located area subsampled on the slide $\left(0.5 \mathrm{~cm}^{2}\right)$. The total number of pollen grains was calculated by relating the number of grains observed in the sampled area to the total surface area of the melted gelatine on the slide. Iris pollen grains were easily distinguished from other pollen grains because of their huge size $(100 \mu \mathrm{m})$, which was not found for any other plant species growing in the same habitat.

\section{Morning flight time tests}

To examine the effect of heat reward on morning emergence time, male bee aggregates (at least two bees.flower-1) found in flower tunnels before sunrise were separated into two groups: one group was placed directly on the ground, while the other was left inside the flower tunnel. Continuous observations were performed until emergence (emergence from the flower or flight of the insects placed on the soil). During the observation period, floral (inside the floral tunnel) and air temperatures (measured at $20 \mathrm{~cm}$ above soil level) were recorded every 15 min using a HD 9010 thermometer (precision: $0.1{ }^{\circ} \mathrm{C}$ ). The exact moment of emergence and the environmental (floral or ambient) temperature at emergence were recorded for each individual. Observations were stopped at 10:00 $\mathrm{h}$ and nonemerged insects were not considered in the analysis. Over the whole flowering season, 12 morning observations were conducted. We tested whether the mean time of emergence (number of minutes from sunrise until flight) differed significantly between the two groups with a paired $t$ test. Mean temperature within the flowers and outside at the time of emergence were compared with a paired $t$ test.

To characterize temperature variation inside and outside the flowers, additional temperature records were taken every hour over 2 whole days from sunrise to sunset.

\section{Insects identification and data analysis}

Collected insects were identified by S. Patigny (Unité de Zoologie générale et Appliquée, FUSAGx, Belgium) for the Andrenidae; M. Terzo and P. Rasmont (Mons-Hainaut University, Belgium) for Xylocopa spp. and Bombus spp., respectively, and A. Pauly for Halictidae. Other groups were identified by the first author using Michener's (2000) classification. All statistical analyses were performed using Minitab software version 14.20 (Minitab Inc. 2000).

\section{Results}

\section{Floral longevity and receptivity}

The first wilting signs appeared after an average of $6.2 \mathrm{~d}$ $( \pm 0.4 \mathrm{SD})$, which represents the actual floral longevity. Flowers that were cross-pollinated on the first day of opening gave $100 \%$ fruiting. For the maximal receptivity test, cross-pollination treatments were performed on the morning of the 6th day. No fruits were produced. Floral receptivity is thus lost before the first wilting signs, and functional female longevity is a maximum of $5 \mathrm{~d}$.

\section{Diurnal observations}

The total frequency of diurnal visits on Iris cedretii was 0.34 and 0.32 visit.flower ${ }^{-1} \cdot \mathrm{h}^{-1}$ in The Cedars and Ain El Haramiyé populations, respectively. Among the 47 recorded species (Table 1), 9 belonging to three groups of solitary bees (Hymenoptera) appeared to be the main flower visitors. These were Eucera spp. (6), Xylocopa spp. (2), and Andrena spp. (1). There were some differences in the relative importance of various groups between the two populations of I. cedretii. In the Ain El Haramiyé population, Xylocopa spp. were the most frequent visitors, and no Andrena spp. were observed (Fig. 2). In the Cedars population, Eucera spp. were the most frequent (77\% of all visits) followed by Xylocopa spp.(Fig. 2). Sheltering was the most common behaviour representing $82.5 \%$ of all visits, but its relative importance varied among groups. Eucera spp. visits were mainly linked to sheltering. In contrast, Xylocopa spp. showed a foraging-like behaviour (foragers) (Fig. 2), flying from flower to flower between clumps, entering and exiting the pollination tunnel over short time periods. This was observed under different climatic conditions, and more often during warm periods of the day. However they entered a few flowers as compared with the number of approaches, and sheltering was less important in this group. The foraging behaviour was also observed for one Anthophora species and two Bombus species, but with a negligible frequency rate (respectively, 3, 1, and 1 occurrence over the whole flowering period). It should be noted that for sheltering 
Table 1. List of insects collected on Iris cedretii in the Cedars and Ain El Haramiyé and on Iris sofarana subsp. kesruwana in Laqlouq.

\begin{tabular}{|c|c|c|c|c|c|}
\hline \multirow[b]{2}{*}{ Taxon } & & \multirow[b]{2}{*}{$\begin{array}{l}\text { No. of } \\
\text { species }\end{array}$} & \multicolumn{3}{|c|}{ No. of collected individuals } \\
\hline & & & The Cedars & $\begin{array}{l}\text { Ain El } \\
\text { Haramyé }\end{array}$ & Laqlouq \\
\hline \multicolumn{6}{|l|}{ HYMENOPTERA } \\
\hline \multicolumn{6}{|l|}{ Anthophoridae } \\
\hline Anthophora Latreille, 1803 & Anthophora spp. & 4 & 7 & 5 & 0 \\
\hline \multirow[t]{4}{*}{ Eucera Scopoli, 1770} & E. (Eucera) spp. & 2 & 180 & 0 & 0 \\
\hline & E. (Hetereucera) sp.Tkalců, 1978 & 1 & 19 & 17 & 0 \\
\hline & E. (Pteneucera) spp. Tkalců, 1984 & 2 & 103 & 0 & 2 \\
\hline & E. (Synhalonia) sp. Patton, 1979 & 1 & 482 & 0 & 22 \\
\hline \multirow[t]{3}{*}{ Xylocopa Latreille, 1802} & X. (Xylocopa) violacea (L.), 1758 & 1 & 18 & 4 & 2 \\
\hline & X. (Xylocopa $)$ valga Gerst., 1872 & 1 & 8 & 3 & 1 \\
\hline & $\begin{array}{l}\text { X. (Proxylocopa) olivieri Lepeletier, } \\
1841\end{array}$ & 1 & 1 & 0 & 0 \\
\hline \multicolumn{6}{|c|}{ 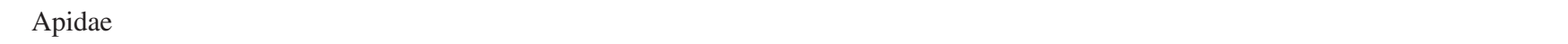 } \\
\hline Apis L., 1758 & A. mellifera (L.), 1758 & 1 & 0 & 2 & 0 \\
\hline \multirow{2}{*}{ Bombus Latreille, 1802} & B. vorticosus Gerst., 1872 & 1 & 1 & 0 & 0 \\
\hline & B. melanurus Lepeletier, 1836 & 1 & 1 & 0 & 0 \\
\hline \multicolumn{6}{|l|}{ Andrenidae } \\
\hline \multirow[t]{7}{*}{ Andrena Fabricius, 1775} & Andrena sp. & 2 & 9 & 0 & 0 \\
\hline & A. (Nobandrena) sp. Warncke, 1968 & 2 & 104 & 0 & 0 \\
\hline & $\begin{array}{l}\text { A. (Melandrena) thoracica kotschyi } \\
\text { Fabricius, } 1775\end{array}$ & 1 & 1 & 0 & 0 \\
\hline & $\begin{array}{l}\text { A. (Melandrena) nigroaena candiae } \\
\text { Strand, } 1945\end{array}$ & 1 & 2 & 0 & 0 \\
\hline & $\begin{array}{l}\text { A. (Melandrena) albopunctata funebris } \\
\text { Panzer, } 1798\end{array}$ & 1 & 1 & 0 & 0 \\
\hline & $\begin{array}{l}\text { A. (Plastandrena) bimaculata Kirby, } \\
1802\end{array}$ & 1 & 2 & 0 & 0 \\
\hline & A. (Zonandrena) flavipes Panzer, 1799 & 1 & 1 & 0 & 0 \\
\hline \multicolumn{6}{|l|}{ Megachilidae } \\
\hline Hoplitis Klug, 1807 & Hoplitis sp. & 1 & 0 & 1 & 0 \\
\hline Osmia Panzer, 1806 & Osmia spp. & 4 & 7 & 10 & 1 \\
\hline Rhodanthidium Isensee, 1927 & Rhodanthidium sp. & 1 & 1 & 0 & 0 \\
\hline Megachile Latreille, 1802 & Megachile sp. & 1 & 1 & 0 & 0 \\
\hline \multicolumn{6}{|l|}{ Halictidae } \\
\hline \multirow[t]{3}{*}{ Lasioglossum Curtis, 1833} & L. euboense Strand, 1909 & 1 & 1 & 0 & 0 \\
\hline & L. lineare Schenck, 1868 & 1 & 1 & 0 & 0 \\
\hline & L. marginatum Brullé, 1832 & 1 & 1 & 7 & 0 \\
\hline Halictus Latreille, 1804 & H. quadricinctus Fabricius, 1776 & 1 & 4 & 0 & 0 \\
\hline Thrincohalictus Pérez, 1910 & T. prognathus Pérez, 1910 & 1 & 0 & 1 & 0 \\
\hline \multicolumn{6}{|l|}{ VESPOIDEA } \\
\hline \multicolumn{6}{|l|}{ Vespidae } \\
\hline Polistes Latreille, 1802 & Polistes sp. & 1 & 5 & 0 & 0 \\
\hline Vespula Thomson, 1869 & Vespula sp. & 1 & 2 & 0 & 0 \\
\hline \multicolumn{6}{|l|}{ COLEOPTERA } \\
\hline Oxythyrea Poda, 1761 & Oxythyrea spp. & 4 & 17 & 16 & 0 \\
\hline Rutelidae & & 1 & 2 & 0 & 0 \\
\hline \multicolumn{6}{|l|}{ HETEROPTERA } \\
\hline \multicolumn{6}{|l|}{ Lygaeidae } \\
\hline Lygaeus Fabricius, 1794 & Lygaeus sp. & 1 & 8 & 1 & 0 \\
\hline Pentatomidae & & 1 & 2 & 0 & 0 \\
\hline \multicolumn{6}{|l|}{ HOMOPTERA } \\
\hline Cercopidae & & & & & \\
\hline Cercopis Fabricius, 1775 & Cercopis sp. & 1 & 1 & 0 & 0 \\
\hline Total & & 47 & 993 & 67 & 28 \\
\hline
\end{tabular}


Fig. 2. Frequency of visits (No. of visits·flower ${ }^{-1} \cdot \mathrm{h}^{-1}$ ) during daytime for the principal Iris visitors (Xylocopa spp., Eucera spp., and Andrena spp.) and their behaviours (sheltered, accidental, foragers), at The Cedars $(a)$ and Ain El Haramiyé (b).

a)

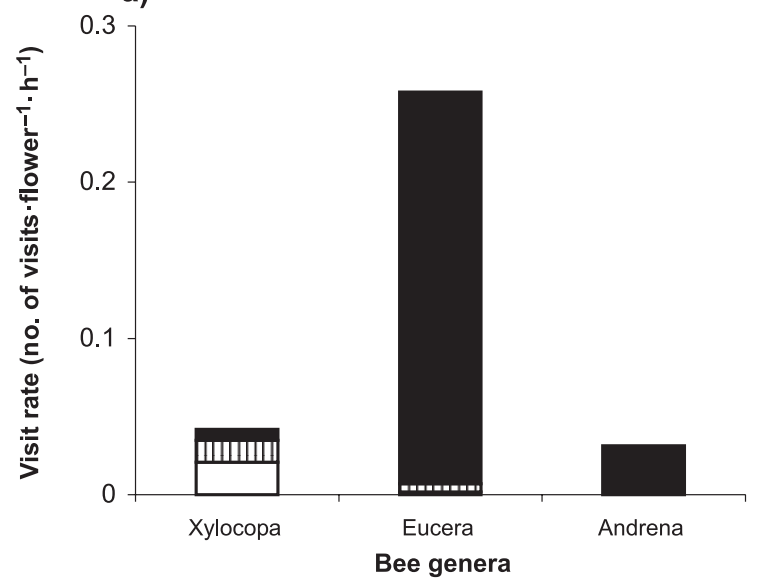

groups such as Eucera spp., the very low rate of visits referred as "foraging" can be interpreted as probing behaviour for checking potential shelters. Other groups such as $\mathrm{Co}$ leoptera, Homoptera, and Heteroptera were observed eating the flowers' tissues and most likely play no role in pollination. For the former in particular, their grouped feeding habit most often leads to the complete destruction of floral receptive parts. Similar groups and behaviours were also found in the I. sofarana subsp. kasruwana population in Laqlouq (Table 1).

\section{Night and day sheltering}

In The Cedars population, the night-shelter phenomenon started 1-4 h before sunset, depending on the climatic conditions. In the morning, bees left the flower $20 \mathrm{~min}$ minimum after sunrise, but could stay inside for hours when the weather was windy or cloudy. From the 700 flowers sampled over 14 nights, $27 \%$ contained at least one insect. Eucera male bees were by far the most frequently involved in the phenomenon, as $89.4 \%$ of flowers containing insects sheltered at least one male Eucera (Table 2). That is to say that $24.1 \%$ of the 700 sampled flowers contained Eucera bees. Aggregates of up to 25 Eucera bees inside one single flower were found $($ mean $=2.484 \pm 3.124 \mathrm{SD})$. Aggregates were either monospecific or contained several species grouped together. The monospecific aggregation phenomenon was reflected by the calculated variance/mean ratios, which are all greater than 1 (ranging from 1.5 to 7.1 ). Moreover, all distributions significantly differ from poisson distribution ( $\chi^{2}$ test: $P<0.001$ for all insect species). Inside the flower, bees could occupy one, two, or the three pollination tunnels.

As during the night, sheltering was recorded during the day, but at a lower occurrence. From the 1350 sampled flowers over $15 \mathrm{~d}, 12 \%$ sheltered at least one insect (mean = $1.856 \pm 1.806 \mathrm{SD}$ ). Among them, 64\% contained Eucera bees (Table 2). Sheltering appeared to be a constant phenomenon, as it was found during all daytime hours (from sunrise until sunset), but refugees' behaviour depended on the weather. They principally flew and fed under sunny conditions and massively sheltered if a cloudy or windy period occurred. In sunny periods, however, $4.9 \%$ of Iris flowers still b)

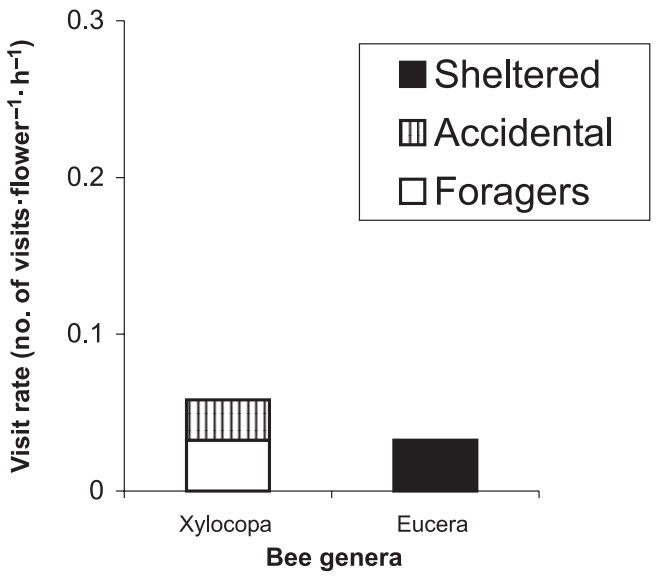

contained Eucera bees against $13.6 \%$ and $18.7 \%$, respectively, under windy and cloudy conditions, for the departure was not instantaneous when the weather improved (Fig. 3). Considering (1) sunny periods; (2) cloudy periods; (3) windy periods, and (4) night periods, there was a highly significant influence of these conditions on the proportion of occupied flowers $\left(\chi^{2}\right.$ test: $\left.\mathrm{df}=2 ; \chi^{2}=40.276 ; P=0.00\right)$. The same groups of insects as during the night were found inside flowers and they also showed an aggregated distribution among flowers as calculated by the variance/mean ratios (range from 1.4 to 5) and by the goodness-of-fit tests for Poisson distribution ( $\chi^{2}$ test: $P<0.001$ for all insect species). Eastoriented and southeast-oriented tunnels were generally preferred by Eucera bees, both during night and day (Fig. 4). For the flowers that were used by insects as night shelters, the average height and diameter were significantly different from the population means for the Pteneucera spp. ( $t$-test height: $T=-3.56$, df $=55, p=0.001$; diameter: $T=-2.46$, df $=55, p=0.017$ ) and Synhalonia spp. ( $t$-test height: $T=-3.12$, df $=136, p=0.002$; diameter: $T=-2.55$, df $=136, p=0.012$ ). The mean height and diameter of the flowers sheltering the different groups of refugees during the day were also significantly different from the population means for the Eucera spp. ( $t$-test height: $T=-2.15$, $\mathrm{df}=55, p=0.036)$, Pteneucera spp. ( $t$-test height: $T=-3.73$, df $=46, p=0.001)$, and Synhalonia spp. ( $t$-test height: $T=-3.63$, df $=60, p=0.001$; diameter: $T=-3.60$, df $=60, p=0.001)$. When differences were significant; taller plants and larger flowers were always preferred by insects.

\section{Influence of flower spatial pattern on frequency of visit and the sheltering phenomenon}

For day visit observation, the number of flowers per clump ranged from 1 to 26 . There were differences in frequency of visits among visitors, according to the number of flowers in the clump. The global rate of visit per flower decreased with the number of flowers in the clump for Xylocopa spp., with a clear preference for isolated flowers (Fig. 5). A general trend for decreasing global rate of visit with increasing number of flowers per clump was also noted for Eucera spp., with a preference for small clumps (up to 4 
Table 2. Visitation rate (No. of visits.flower ${ }^{-1} \cdot \mathrm{h}^{-1}$ ) and proportion of the different groups in the sheltering phenomenon (\% of flowers occupied by each group among flowers sheltering insects; the totals do not add up to $100 \%$, because the same flower can shelter different groups of insects).

\begin{tabular}{llcc}
\hline & & \multicolumn{2}{c}{$\begin{array}{l}\text { Sheltering (\% of flower } \\
\text { occupied by each group) }\end{array}$} \\
\cline { 3 - 4 } & $\begin{array}{l}\text { Visitation rate } \\
\text { (visit·flower }{ }^{-1} \cdot \mathrm{h}^{-1} \text { ) }\end{array}$ & Day & Night \\
\hline Euxon & 0.258 & 64 & 89.4 \\
Eucera spp. & 0.005 & 1.8 & 4.3 \\
Eucera (Eucera s.str.) spp. & 0.07 & 24.4 & 6.9 \\
Eucera (Pteneucera) spp. & 0.03 & 14 & 17 \\
Eucera (Synhalonia) spp. & 0.153 & 23.8 & 61.2 \\
Xylocopa spp. & 0.042 & 1.2 & 1.1 \\
Xylocopa violacea & 0.03 & 0 & 0.5 \\
Xylocopa valga & 0.009 & 0.6 & 0.5 \\
Andrena spp. & 0.031 & 23.8 & 16.5 \\
Other Hymenoptera & 0.03 & 11 & 2.7 \\
Other groups & 0.021 & 7.9 & 1.1 \\
Oxythyrea spp. & 0.014 & 2.4 & 0 \\
Total & 0.339 & 107.927 & 110.6 \\
\hline
\end{tabular}

flowers) as compared with larger ones. In Andrena, a trend appeared for a higher global rate of visit in clumps with an intermediate number of flowers, but as the rate of visit was rather low for all clump sizes, the pattern is difficult to interpret.

For the night-sheltering observations, the number of flowers per clump ranged from 1 to 18 , and the density of flowers within a $1 \mathrm{~m}^{2}$ circle varied from 1 to 17 . As the number of flowers and the density were highly correlated (Pearson correlation, $r=0.794, P=0.000)$, only the results based on flowers number per clump are presented (Fig. 6). Night sheltering was most frequent in solitary flowers or two-flowered clumps (Fig. 6), and an occupation of the three tunnels simultaneously was found only for these categories. Clump size and flower density have thus an impact on the sheltering behaviour. Bees are most likely to choose isolated flowers located in areas with low flowering densities.

For day-sheltering occurrence, the trend is less obvious, it seemed related to the number of flowers in the clump for the categories below eight flowers (Fig. 6).

\section{Pollen quantification}

Pollen loads were quantified for the main groups of foragers (Xylocopa spp.) and refugees (Eucera spp.). Pollen was collected from all parts of the insect's body, but it was mainly located on the thorax. Pollen quantities increased with body size and ranged from 1.4 ( \pm 3.2 SD) to 296.7 ( \pm 211.1 SD) pollen grains (Fig. 7). However, a high variation of pollen loads was observed even within groups. For example, pollen quantities on Xylocopa violacea varied between 12 and 769 pollen grains carried per individual. Quantities carried by $X$. valga were much lower and reflected a more generalist foraging behaviour, as Iris pollen represented on average $45 \%$ of total carried pollen, while this proportion reached $66.25 \%$ for $X$. violacea. Eucera spp. carried much less pollen than Xylocopa spp.

\section{Morning flight time tests}

Insects inside the flowers did not emerge before those placed on the ground. The flight time of the latter was significantly earlier than that of individuals sheltering in the flowers (paired $t$ test (mean number of minutes from sunrise until flight): $T=-4.95$; df $=19 ; P=0.000$ ). Male bees that took refuge in the flowers for the night left their shelter at the earliest $21 \mathrm{~min}$ after the direct contact of the sun on the flower, while insects on the ground left at the earliest $1 \mathrm{~min}$ after the first sun rays reached the site. Average morning flight time was 83 min after the arrival of sun rays on the flowers. The first flight from the flower happened at an average temperature of $18.4{ }^{\circ} \mathrm{C}( \pm 3.2 \mathrm{SD})$ while on the ground, insects flew away as soon as they could move, with a recorded average air temperature of $13.8{ }^{\circ} \mathrm{C}( \pm 1.9 \mathrm{SD})$. These two departure temperatures were significantly different (paired $t$ test: $T=-5.30$; df $=19 ; P=0.000$ ).

Day mean difference between floral and air temperature varied from $0.9{ }^{\circ} \mathrm{C}$ to $2.0{ }^{\circ} \mathrm{C}$ with temperature inside the flower always being higher. The evolution of the mean temperature difference between flower and air is depicted in Fig. 8.

\section{Discussion}

\section{Flower frequentation and pollination efficiency}

Comparative studies of pollen deposition on the stigmatic surface or measurements of seed set after visitations are the best estimates of visitors' pollination efficiency (Kearns and Inouye 1993). However, direct methods for evaluating pollinator efficiency in a plant species with numerous visitors are not convenient, because measurement of each insect visitor species is prohibitive (Lindsey 1984; Jacquemart 1993; Mahy and Jacquemart 1998). In this study, observations of visitors' behaviour, pollen load, and frequency of visit were used to determine the potential efficiency of visitors.

In the examined population of Oncocyclus irises, each 
Fig. 3. Proportion of flowers sheltering bees and spatial location of the bees inside the flower (occupying one, two, or the three pollination tunnels) at night and during the day under three climatic conditions (cloudy, windy, sunny) at The Cedars.

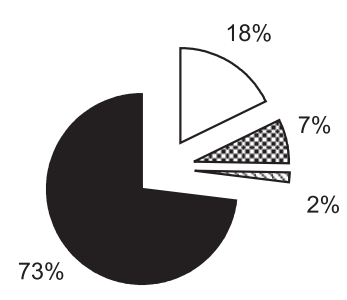

Night

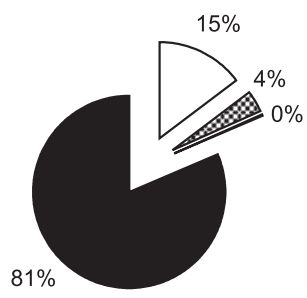

Cloudy (day)

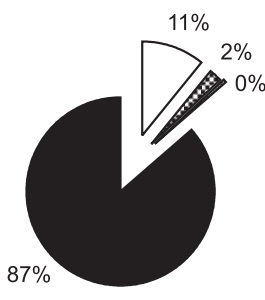

Windy (day)

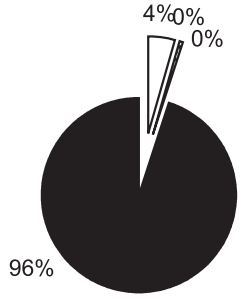

Sunny (day) $\square$ Bees sheltered in 1 tube

Q Bees sheltered in 2 tubes

Bees sheltered in 3 tubes

Empty flowers

Fig. 4. Relative proportion of bees found inside pollination tunnels in relation to the orientation of the tunnel, at night and during the day at The Cedars.

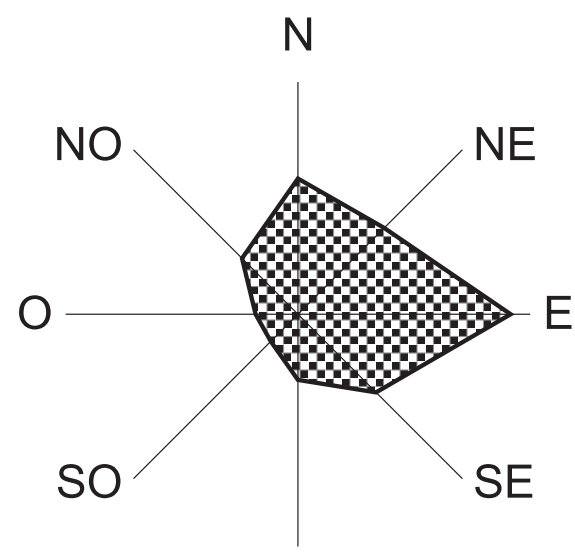

S

\section{Night}

Fig. 5. Frequency of visits (No. of visits $\cdot$ flower $^{-1} \cdot \mathrm{h}^{-1}$ ) for Xylocopa spp., in relation to the number of flowers per clump, during daytime at The Cedars.

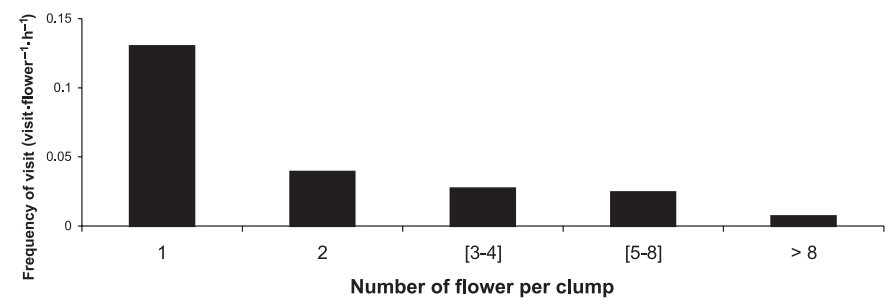

flower is visited approximately once every $3 \mathrm{~h}$. Nevertheless, those flowers are visited by a huge diversity of insects: 47 insect species, belonging to four orders, were recorded over the whole study. Among those species, an important part is most likely not linked to pollen transfers because of little size, poor hairiness (e.g., Andrenidae), or herbivorous behaviour (e.g., bugs and beetles). Ultimately, only two groups of Anthophoridae male bees can be considered as efficient and common pollinators of Oncocyclus irises in Lebanon: Xylocopa spp. and Eucera spp. The anatomy of these can allow significant pollen transportation, and they are found in flowers at much higher rates than other groups.

\section{Xylocopa bees pollination}

The two main species of Xylocopa (carpenter bee) found

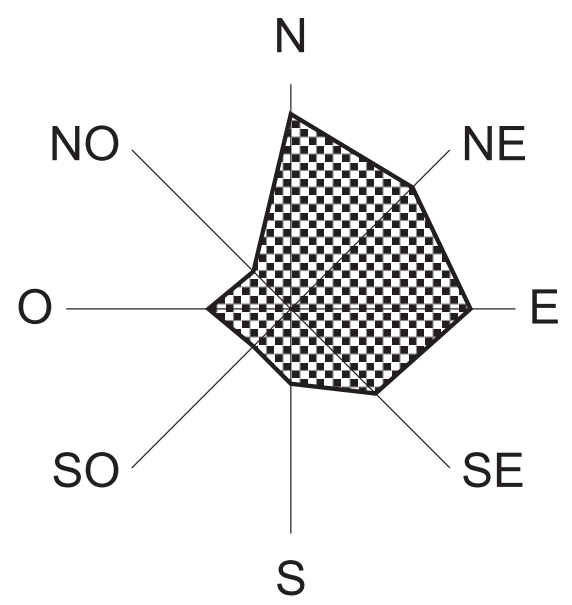

\section{Day}

Fig. 6. Proportion of flowers sheltering bees at night (a) and during the day $(b)$ in relation to the number of flowers per clump and spatial location of the bees inside the flowers (occupying one, two, or the three pollination tunnels).
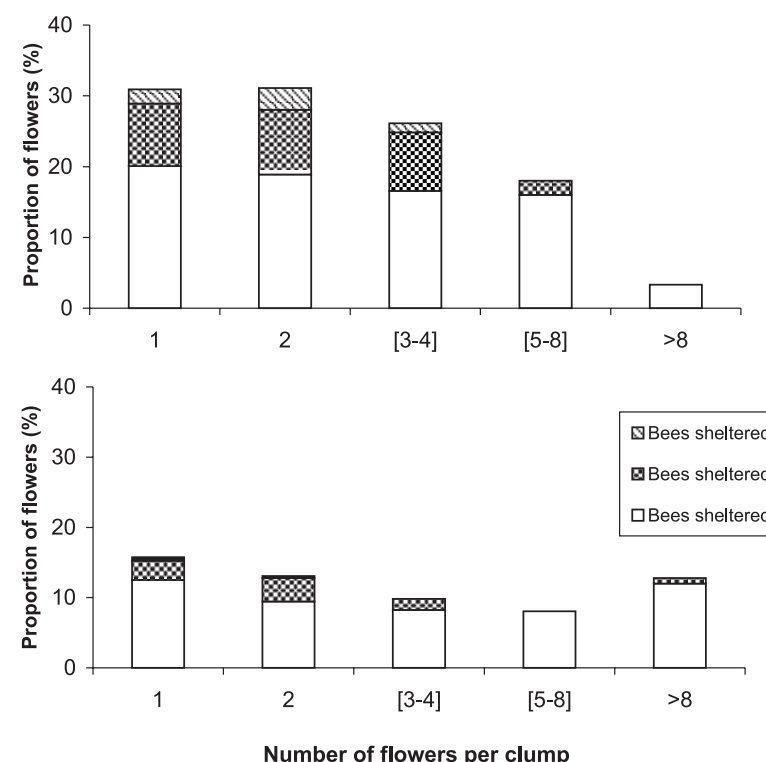
Fig. 7. Average number of pollen grains collected on the bodies of the main pollinator groups (Xylocopa spp. and Eucera spp.).
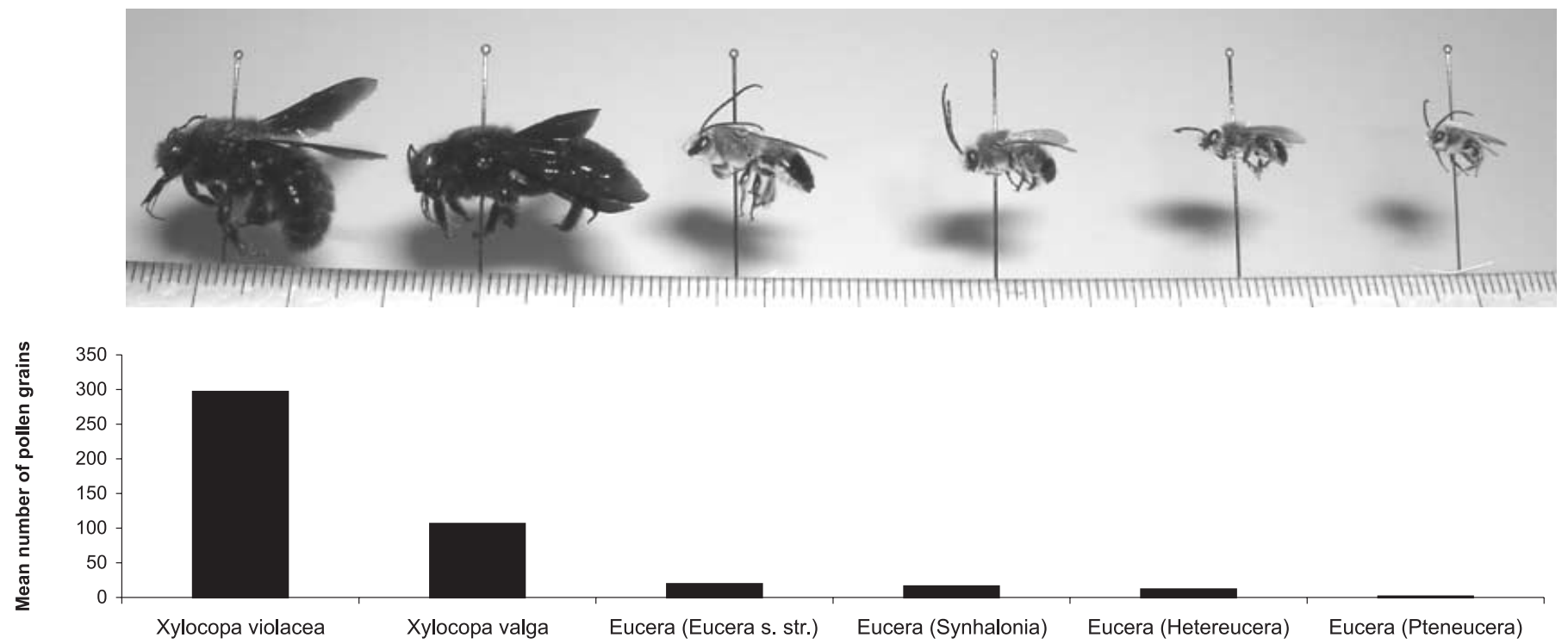

in Oncocyclus populations, X. violacea and X. valga, are dark large hairy bees (around $25 \mathrm{~mm}$ long). Taking into account the frequency of visit of both species $\left(0.042\right.$ visits $\cdot$ flower $\left.^{-1} \cdot \mathrm{h}^{-1}\right)$, if bees are present $12 \mathrm{~h}$ a day and if the flowers stigmas are receptive for a maximum of $5 \mathrm{~d}$, each Iris flower could be visited on average 1.67 times by carpenter bees. However this may be an overestimate because (1) several visits can occur in the same tunnel, (2) pollen flows can occur between flowers of the same genet, and (3) the presence of carpenter bees in the Iris population is not continuous. Considering the insect anatomy and that of the floral tunnel, it appears that one single visit of any of the two species may lead to deposit more pollen grains than needed for the fecundation of ovules contained in the carpel (30-50 ovules, L. Saad, data not included). Carpenter bees can thus be considered as efficient pollinators of Oncocyclus irises.

\section{Shelter pollination}

Eucera males are hairy bees, 9-17 $\mathrm{mm}$ long. This group is by far the most commonly involved in the flower-sheltering phenomenon in Lebanese Oncocyclus irises. In addition to the study of Sapir et al. (2005) on Oncocyclus irises from Israel, flowers from several other plant species have already been reported as night shelters for aggregations of solitary bees, especially male. Eucera males were found in Anemone coronaria (Horovitz 1976), males of Eucera, Andrena, Tetralonia, and Osmia were recorded in Serapias vomeracea (Dafni et al. 1981), Perdita texana spend the night in Opuntia flowers (Danforth and Neff 1992), males of Perditomorpha brunerii spend the night in Sida spp. (Gaglianone 2000), and Peponapis and Xenoglossa bees shelter in Cucurbita sp.(Willis and Kevan 1995). In only two cases (Dafni et al. 1981; Sapir et al. 2005), the role of night-sheltering male bees as pollinators was demonstrated.

The morning flight time tests and diurnal observations indicate that the principal advantage for male bees to shelter in Iris flowers is not especially to fly earlier in the morning. Floral tunnels are in fact used as a refuge, providing relative security and a higher temperature to insects, thus reducing their energy losses. These rewards are accentuated by the aggregation tendency of Eucera male bees. Aggregation provides a predation-risk dilution for each individual, and limits the energy losses during the night and cold periods. As aggregated bees are less numb, they can react faster in case of predation. Orientation preference also enforces the floralsheltering rewards when bees choose a refuge. Eastern (and southeastern) oriented tunnels, which are the less exposed to the prevailing winds and are the fastest to be warmed by the sun, are preferred. This suggests that bees could be able to learn which floral tunnel is the most attractive and provides the best chances of reducing energy losses.

During daytime at the Cedars, Eucera male bees are on average found sheltering in $7.8 \%$ of iris flowers. This percentage reaches $24.1 \%$ at night. With a flower receptivity of maximum $5 \mathrm{~d}$ (and nights), each flower could be used 1.6 times as a shelter by Eucera bees. Night sheltering is quantitatively superior but is a longer phenomenon, bees being still during the main part of the night. If a long sheltering time can deposit more pollen grains on insects, pollen transfers between flowers are due to shelter succession (and shelter probing). Day sheltering is thus qualitatively very important for pollination, especially when sunny periods alternate with cloudy or windy weather.

The different Eucera species are not similarly efficient for pollination: E. (Eucera) spp. and E. (Synhalonia) spp., the most frequent species in The Cedars and Laqlouq, which carry the higher quantities of pollen, are the biggest and the most hairy species. Eucera (Hetereucera) males come third, but are the only ones recorded in Ain El Haramiyé. Eucera (Pteneucera) spp. are by far the less efficient species, because of the low pollen quantities that they carry. All the same, Eucera males carried fewer pollen grains than Xylocopa, and one single visit should be less efficient to ensure 
Fig. 8. Evolution of the mean temperature difference (flower temperature - air temperature) during daytime at the Cedars, with standard deviation and number of observations.

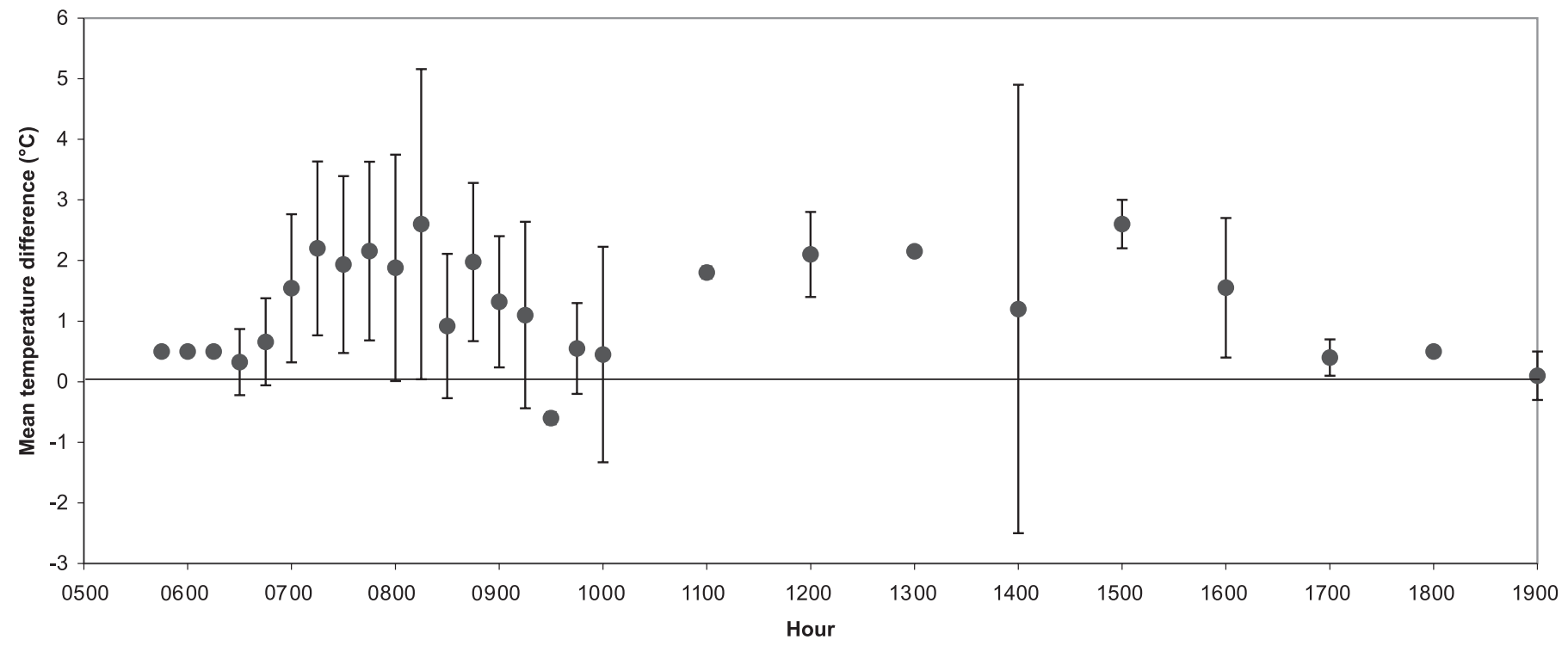

the pollination of a flower tunnel. When bees are aggregated, however, enough pollen could be left on the stigma during one sheltering event.

\section{Flower density and pollination}

From previous studies on various plant-pollinator systems, it appears that the influence of local flowering density on perflower visitation rate seems to be idiosyncratic to each plant and pollinator system (Bosch and Waser 1999; Grindeland et al. 2005; Kirchner et al. 2005). In our case, we examined this relationship in a clonal rhizomatous species that bears a single flower per ramet. In the absence of precise study of clonality in this species, we cannot ascertain whether a clump of ramets corresponds with a single genet or not, but it does not preclude conclusions on the influence of flower density on pollinators attractions.

We found that the visitation rate of both day-visiting $X y$ locopa and night-sheltering Eucera were influenced by the number of flowers per clumps (correlated to local flower density).

Isolated and sparse flowers are more often visited by $X y$ locopa spp., and the visitation rate (per flower) decreases when the number of flowers per clump increases. The Xylocopa foraging-like behaviour in Iris population is most probably induced by another mechanism than food rewards. Further research is needed to completely understand the attraction process of male carpenter bees to Oncocyclus flowers. The role of the onco spot in hole mimicry (Dafni et al. 1981) or even in sexual deception (but see Nilsson 1992) should be investigated.

Frequentation by night-sheltering Eucera spp. depends on flower density and number of flowers per clump with an apparent preference for isolated (or sparse) flowers. These insects mainly feed upon flowers of the Fabacae family. Areas sparse in irises are often denser in nourishing plants.
In those areas, where Eucera male bees feed, the choice is restricted if they search for a shelter, and each flower will then have a higher probability of sheltering bees than in areas with higher iris densities.

\section{Conclusion}

The present study shows that Lebanese Oncocyclus irises have a bimodal pollination system, including two complementary modes. Visits by Xylocopa spp. occur principally during warm periods of the day, at a very low frequency but with potentially important pollen transfers. Refugees, especially Eucera male bees, are the main visitors and act as the main pollinators during the nights and days when the weather is changeable. Our results are complementary to those of Sapir et al. (2005), showing that, in Oncocyclus irises from Israel, pollination was due to solitary male bees that shelter at night. We then confirmed the prediction of Avishai and Zohary (1980), that large bees (e.g., carpenter bees) can also play a role in the pollination of Oncocyclus irises, while it is the first time that supporting data on Xylocopa frequentation are presented.

This pollination bimodality can be seen as an advantage for the plant, because it reduces its dependence on each insect group population and on climate, which can vary from year to year in Lebanese mountains. This is illustrated with the variation of the relative importance of Xylocopa spp. and Eucera spp. Xylocopa were more important in the Ain El Haramiyé population that began to flower $10 \mathrm{~d}$ earlier than The Cedars population and ended flowering earlier because of herbivory on flowers. Differences in regional climate may be a factor explaining the differences in pollination systems between Israeli and Lebanese Oncocyclus irises.

\section{Acknowledgements}

The authors thank S. Patigny (Unité de Zoologie générale 
et appliquée, FUSAGx, Belgium), M. Terzo, P. Rasmont (Mons-Hainaut University, Belgium), and A. Pauly for their help in the identification of insects, as well as Brian Mathew for the review and suggestions about this manuscript. This research was supported by a grant from the Belgian F.R.I.A. (Fonds pour la recherche dans l'industrie et l'agriculture) to Layla Saad. Arnaud Monty is currently recipient of a Belgian "aspirant FNRS" fellowship (Fonds national de la recherche scientifique).

\section{References}

Avishai, M. 1977. Species relationships and cytogenetic affinities in section Oncocyclus of the genus Iris. Ph.D. thesis, Hebrew University, Jerusalem.

Avishai, M., and Zohary, D. 1980. Genetic affinities among the Oncocyclus irises. Bot. Gaz. 141: 107-115. doi:10.1086/337130.

Baker, H.G., and Hurd, P.D. 1968. Intrafloral ecology. Annu. Rev. Entomol. 13: 385-414. doi:10.1146/annurev.en.13.010168.002125.

Beattie, A.J. 1971. A technique for the study of insect-borne pollen. Pan-Pac. Entomol. 47: 82.

Bosch, M., and Waser, N.M. 1999. Effects of local density on pollination and reproduction in Delphinium nuttallianum and Aconitum columbianum (Ranunculaceae). Am. J. Bot. 86: 871-879. doi:10.2307/2656707. PMID:10371728.

Dafni, A., Ivri, Y., and Brantjes, N.B.M. 1981. Pollination of Serapias vomeracea Briq. (Orchidaceae) by imitation of holes for sleeping solitary male bees (Hymenoptera). Acta Bot. Neerl. 30: 69-73.

Dafni, A., Kevan, P.G., and Husband, B.C. 2005. Practical pollination biology. Enviroquest, Cambridge, UK.

Danforth, B.N., and Neff, J.L. 1992. Male polymorphism and polyethism in Perdita texana (Hymenoptera, Andrenidae). Ann. Entomol. Soc. Am. 85: 616-626.

Emms, S.K., and Arnold, M.L. 2000. Site-to-site differences in pollinator visitation patterns in a Louisiana Iris hybrid zone. Oikos, 91: 568-578. doi:10.1034/j.1600-0706.2000.910319.x.

Faegri, K., and Van Der Pijl, L. 1980. The principles of pollination ecology, 3rd ed. Pergamon Press, Oxford.

Fleming, P.A., and Nicolson, S.W. 2002. How important is the relationship between Protea humiflora (Proteaceae) and its nonflying mammal pollinators? Oecologia, 132: 361-368.

Gaglianone, M.C. 2000. Behavior on flowers, structures associated to pollentransport and nesting biology of Perditomorpha brunerii and Cephalourgus anomalus (Hymenoptera: Colletidae, Andrenidae). Rev. Biol. Trop. 48: 89-99.

Galen, C., and Stanton, M.L. 2003. Sunny-side up: flower heliotropism as a source of parental environmental effects on pollen quality and performance in the snow buttercup, Ranunculus adoneus (Ranunculaceae). Am. J. Bot. 90: 724-729.

Gibernau, M., Barabé, D., Cerdan, P., and Dejean, A. 1999. Beetle pollination of Philodendron solimoesense (Araceae) in French Guiana. Int. J. Plant Sci. 160: 1135-1143. doi:10.1086/314195. PMID:10568780.

Grindeland, J.M., Sletvold, N., and Ims, R.A. 2005. Effects of floral display size and plant density on pollinator visitation rate in a natural population of Digitalis purpurea. Funct. Ecol. 19: 383-390. doi:10.1111/j.1365-2435.2005.00988.x.

Groom, M.J. 1998. Allee effects limit population viability of an annual plant. Am. Nat. 151: 487-496. doi:10.1086/286135.

Heinrich, B., and Raven, P.H. 1972. Energetics and pollination ecology. Science (Washington, D.C.), 176: 597-602. doi:10. 1126/science.176.4035.597.

Herrera, C.M., and Pellmyr, O. 2002. Plant-animal interactions. An evolutionary approach. Blackwell Science, Oxford.
Horovitz, A. 1976. Edaphic factors and flower color distribution in the Anemonae (Ranunculaceae). Plant Syst. Evol. 126: 239-242. doi:10.1007/BF00983363.

International Union for Conservation of Nature and Natural Resources (IUCN). 2000. Red list of threatened species [online]. The IUCN Species Survival Commission (Editors). IUCN, Cambridge. Available from www.redlist.org.

Ishii, H.S., and Sakai, S. 2001. Implications of geitonogamous pollination for floral longevity in Iris gracilipes. Funct. Ecol. 15: 633-641. doi:10.1046/j.0269-8463.2001.00560.x.

Jacquemart, A.L. 1993. Floral visitors of Vaccinium species in the High Ardennes, Belgium. Flora, 188: 263-273.

Kearns, C.A. 2001. North American Dipteran pollinators: assessing their value and conservation status. Conserv. Ecol. 5: 5.

Kearns, C.A., and Inouye, D.W. 1993 Techniques for pollination biologists. University Press of Colorado, Niwot, Colorado.

Kearns, C.A., Inouye, D.W., and Waser, N.M. 1998. Endangered mutualisms: the conservation of plant-pollinator interactions. Annu. Rev. Ecol. Syst. 29: 83-112. doi:10.1146/annurev. ecolsys.29.1.83.

Kevan, P.G. 1975. Sun-tracking solar furnaces in High Artic flowers: significance for pollination and insects. Science (Washington, D.C.), 189: 723-726.

Kevan, P.G. 2001. Pollination: Plinth, pedestal, and pillar for terrestrial productivity. The why, how, and where of pollination protection, conservation, and promotion. In Bees and crop pollination - Crisis, crossroads, conservation. Edited by C.S. Stubbs and F.A. Drummond. Thomas Say Publications in Entomology, Entomological Society of America, Lanham, Md. pp. 7-68.

Kevan, P.G., and Baker, H.G. 1983. Insects as flower visitors and pollinators. Annu. Rev. Entomol. 28: 407-453. doi:10.1146/ annurev.en.28.010183.002203.

Kirchner, F., Luijten, S.H., Imbert, E., Riba, M., Mayol, M., González-Martinez, C., Mignot, A., and Colas, B. 2005. Effects of local density on insect visitation and fertilization success in the narrow-endemic Centaurea corymbosa (Asteraceae). Oikos, 111: 130-142. doi:10.1111/j.0030-1299.2005.14022.x.

Lindsey, A.H. 1984. Reproductive biology of Apiaceae. I. Floral visitors to Thaspium and Zizza and their importance in pollination. Am. J. Bot. 71: 375-387. doi:10.2307/2443496.

Mahy, G., and Jacquemart, A.L. 1998. Mating system of Calluna vulgaris: self-sterility and outcrossing estimations. Can. J. Bot. 76: $36-42$.

Mathew, B. 1989. The Iris. Batsford, London.

Michener, C.D. 2000. The bees of the world. Johns Hopkins University Press, Baltimore. Md.

Minitab. 2000. MINITAB 13.1. Minitab, State College, Penn.

Molina-Freaner, F., Rojas-Martinez, A., Fleming, T.H., and Valiente-Banuet, A. 2004. Pollination biology of the columnar cactus Pachycereus pectin-arboriginum in north-western México. J. Arid Environ. 56: 117-127. doi:10.1016/S0140-1963(02)00323-3.

Nilsson, L.A. 1988. The evolution of flowers with deep corolla tubes. Nature (London), 334: 147-149. doi:10.1038/334147a0.

Nilsson, L.A. 1992. Orchid pollination biology. Trends Ecol. Evol. 7: 255-259.

Passarelli, L., and Bruzzone, L. 2004. Significance of floral colour and scent in three Solanum sect. Cyphomandropsis species (Solanaceae) with different floral rewards. Aust. J. Bot. 52: 659-667. doi:10.1071/BT03008.

Proctor, M., and Yeo, P. 1973. The pollination of flowers. Collins, London.

Rix, M. 1997. Section Oncocyclus. In A guide to species irises. The Species Group of the British Iris Society (Editor). Cambridge Press, London. pp. 62-89. 
Sapir, Y., and Shmida, A. 2002. Species concepts and ecogeographical divergence of Oncocyclus irises. Isr. J. Plant Sci. 49: 229-235.

Sapir, Y., Shmida, A., Fragman, O., and Comes, P. 2002. Morphological variation of the oncocyclus Irises in the Southern Levant. Bot. J. Linn. Soc. 139: 369-382. doi:10.1046/j.10958339.2002.00067.x.

Sapir, Y., Shmida, A., and Ne'eman, G. 2005. Pollination of Oncocyclus irises (Iris: Iridaceae) by night-sheltering male bees. Plant Biol. 7: 417-424. doi:10.1055/s-2005-837709. PMID:16025415.

Seymour, R.S., and Schultze-Motel, P. 1997. Heat-producing flowers. Endeavour, 21: 125-129. doi:10.1016/S0160-9327(97) 80222-0.

Seymour, R.S., White, C.R., and Gibernau, M. 2003. Heat reward for insect pollinators. Nature (London), 426: 243-244. doi:10. 1038/426243a. PMID:14628037.
Sokal, R.R., and Rohlf, F.J. 2003. Biometry. 3rd ed. W.H. Freeman \& Co., New York.

Tarasjev, A. 2005. Impact of genet size and flowering stage on fruit set in Iris pumila L. clones in wild. Acta Oecol. 27: 93-98. doi:10.1016/j.actao.2004.09.007.

Thien, L.B., Azuma, H., and Kawano, S. 2000. New perspectives on the pollination biology of basal angiosperms. Int. J. Plant Sci. 161: S225-S235. doi:10.1086/317575.

Totland, O. 1996. Flower heliotropism in an alpine population of Ranunculus acris (Ranunculaceae): effects on flower temperature, insect visitation, and seed production. Am. J. Bot. 83: 452-458. doi:10.2307/2446214.

Willis, D.S., and Kevan, P.G. 1995. Foraging dynamics of Peponapis pruinosa (Hymenoptera: Anthophoridae) on pumpkin $(\mathrm{Cu}-$ curbita pepo) in southern Ontario. Can. Entomol. 127: 167-175. 